\title{
PENUGASAN TUTOR DI LABORATORIUM SEJARAH SEBAGAI PENGUAT KREATIFITAS MAHASISWA
}

\author{
Lalu Murdi ${ }^{1}$, Bambang Eka Saputra ${ }^{2}$ \\ ${ }^{1,2}$ Universitas Hamzanwadi \\ ${ }^{1}$ lalumurdi2014@gmail.com
}

\begin{abstract}
Abstrak
Penelitian ini bertujuan untuk menganalisis pentingnya media dalam pembelajaran sejarah yang tidak hanya menggunakan digital sesuai dengan perkembangan dewasa ini dengan era 4.0, namun sekaligus juga bagaimana seorang guru mampu menjembatani masa lalu dengan menghadirkan artefak, peninggalan, gambar, bahkan miniatur masa lalu tersebut untuk lebih mudah dipahami. Keberadaan laboratorium atau museum dalam hal ini dapat menjadi jembatan langsung untuk menghubungkan apa yang mereka pelajari dengan realitas empirisnya pada masa lalu. Penelitian ini menggunakan pendekatan kualitatif dengan metode fenomenologi dengan beberapa metode pengumpulan data mulai dari wawancara, observasi, studi dokumen dan dokumentasi. Hasil penelitian menunjukkan bahwa mahasiswa yang terlibat sebagai totor yang ditugaskan untuk menjelaskan setiap priode dengan beberapa media yang tersedia di Laboratorium pendidikan sejarah Universitas Hamzanwadi menunjukkan banyak perkembangan mulai dari kemampuan untuk memahami konteks historis pada periode tertentu maupun kemampuan mereka untuk menjelaskan pada publik atau siswa yang biasanya berkunjung ke laboratorium tersebut. Satu pendekatan menarik yang coba dikembangkan program studi pendidikan sejarah Universitas Hamzanwadi beberapa tahun belakangan ini adalah menjadikan mahasiswa sebagai tutor untuk menjelaskan pada siswa yang berkunjung ke laboratorium pendidikan sejarah. Mahasiswa yang bertugas diacak setiap semester secara bergantian, sehingga masing-masing diantara mereka benar-benar memahami setiap benda-benda bersejarah sesuai yang ditugaskan.
\end{abstract}

Kata Kunci: Penugasan Tutor, Media Pembelajaran, Laboratorium.

\begin{abstract}
This study aims to analyze the importance of media in the history of learning that not only uses digital in accordance with current developments with era 4.0, but also how a teacher is able to bridge the past by presenting artifacts, relics, images, even miniatures of the past for easier understood. The existence of a laboratory or museum in this case can be a direct bridge to connect what they have learned with their empirical reality in the past. This research uses a qualitative approach with a phenomenological method with several methods of data collection ranging from interviews, observations, document studies and documentation. The results showed that students involved as totor who were assigned to explain each period with some media available at the Hamzanwadi University history education laboratory showed many developments starting from the ability to understand the historical context at a certain period and their ability to explain to the public or students who normally visit the laboratory. One interesting approach that Hamzanwadi University's history education program has tried to develop in recent years is to make students as tutors to explain to students who visit the history education laboratory. Students who are assigned are randomized every semester in turn, so that each of them truly understands each historical object as assigned.
\end{abstract}

Keywords: Assignment of Tutors, Learning Media, Laboratory. 


\section{PENDAHULUAN}

Perkembangan media pembelajaran dewasa ini yang sangat maju terutama dengan dukungan teknologi digital yang sangat masif sudah tentu membawa perubahan yang signifikan terhadap cara pandang dalam penggunaan media yang sebelumnya banyak menggunakan media-media konvensional. Meskipun demikian, pada materi-materi tertentu media-media yang dihadirkan secara konvensional akan tetap penting untuk digunakan sehingga akan lebih mudah dan cepat untuk dipahami.

Mata pelajaran tertentu seperti sejarah harus digunakan media yang beragam untuk dapat menghadirkan masa lalu tersebut lebih dekat mulai dari film-film sejarah, animasi, dan media lainnya dalam bentuk digital. Disamping itu, selain siswa diajak berselancar dalam bentuk digital, mereka juga akan lebih termotivasi apabila diajak dan dapat melihat, memagang langsung artifak dan bukti sejarah lainnya meskipun dalam bentuk miniatur. Dalam konteks metode belajar contectual teaching and learning seperti dijelaskan Blanchard (al-Tabani, 2015: 139), "pembelajaran yang terjadi dalam hubungan yang erat dengan pengalaman sesungguhnya" dalam hal ini sangat relevan untuk dikembangkan.

Keberadaa museum atau laboratorum sejarah dalam hal ini dapat dianggap sebagai bagian dari media konvensional yang menghimpun banyak peninggalan sejarah baik yang asli maupun merupakan hasil rekonstruksi ulang bahkan dihadirkan dalam bentuk miniatur. Keberadaan laboratorium sejarah atau museum sampai saat ini sepertinya masih menjadi tempat yang penting bagi siswa khsusunya untuk secara langsung melihat peninggalan-peninggalan sejarah sehingga merasa lebih dekat dengan materi yang dijelaskan oleh guru. Pendekatan pembelajaran semacam ini juga dapat dianggap sebagai metode pembelajaran karyawisata bagi siswa (Aman, 2011: 117).

Adanya motivasi yang lebih untuk memahami sejarah dengan menhhadirkan peninggalan-peninggalan tersebut tidak hanya berpengaruh dalam meningkatkan pemahaman dan motivasi siswa untuk belajar, pada tingkat yang lebih tinggi sekaligus dapat menjadi penguat bagi mahasiswa untuk dapat memahami konteks historisnya lebih mendalam. Lebih dari itu bahkan mereka dapat menghadirkan bukti dan peninggalan masa lalu tersebut dalam bentuk miniatur.

Satu pendekatan menarik yang coba dikembangkan program studi pendidikan sejarah Universitas Hamzanwadi beberapa tahun belakangan ini adalah menjadikan mahasiswa sebagai tutor untuk menjelaskan pada siswa yang berkunjung ke laboratorium pendidikan sejarah. Mahasiswa yang bertugas diacak setiap semester secara bergantian, 
sehingga masing-masing diantara mereka benar-benar memahami setiap benda-benda bersejarah sesuai yang ditugaskan.

Sangat berbeda dengan tugas-tugas yang diberikan pada proses perkuliahan, tugas menjadi tutor sangat disenangi oleh mahasiswa meskipun mereka tidak mendapatkan nilai. Salah satu yang menyebabkan mereka lebih antusias untuk mempelajari konteks historis setiap peninggalan sejarah selain karena adanya kunjungan siswa yang menyebabkan mereka memiliki panggung tersendiri sekaligus mereka merasa lebih mudah untuk mengingat apabila dilengkapi dengan media. Namun satu hal yang penting untuk mendapatkan perhatian dalam hal ini adalah keterlibatan mereka menjadi tutor untuk bisa dikenal oleh siswa dari beberapa sekolah sebenarnya merupakan motivasi tersendiri.

Keterlibatan mahasiswa sebagai tutor atau diberikan peran yang besar untuk berekspresi melalui media-media di Laboratorium dan tempat-tempat yang lain sangat memungkinkan mahasiswa untuk lebih antusias belajar mempersiapkan dirinya, terlebih alagi apabila ada motivasi ekstrinsik yang kuat sehingga mereka lebih termotivasi. Memberikan panggung kepada mereka seperti kasus penugasan sebagai totor pada mahasiswa di program studi pendidikan sejarah di Universitas Hamzanwadi juga dapat dilakukan pada tingkat SLTA ke bawah.

Terdapat dua keuntungan dalam proses pembelajaran yang demikian, pertama, memberikan motivasi dan kemampuan mahasiswa untuk mengeksplorasi serta berekspresi dengan membuat panggung sendiri. Dan hal ini tentunya sebagai bagian dari cara untuk membuat mereka sadar bahwa dalam proses pembelajaran sejarah diperlukan media yang beragam yang sesuai dengan kebutuhan setiap materi yang berbeda-beda. Kedua, keterlibatan siswa untuk melihat langsung benda-benda atau peninggalan sejarah akan semakin memberikan ruang yang lebih baik pada genersi muda untuk memahami sejarah dengan lebih baik. Melalui kunjungan semacam ini akan terbentuk kecintaan terhadap masa lalu yang lebih baik lagi. Keuntungan lain adalah dimungkinkan pembelajaran menjadi menarik, siswa merasa senang sebab tema-tema sejarah disesuaikan dengan minat siswa (Agung, \& Sri Wahyuni. 2013: 68).

Bagik bagi mahasiswa dan siswa, proses pembelajaran seperti ini sekaligus sebagai bagian dari proses integrasi pemahaman dari yang lebih spesifik menuju pembelajaran sejarah yang lebih kompleks seperti sejarah nasional dan internasional. Tulisan Badarudin \& Lalu Murdi (2016), dalam dalam kaitannya dengan hal tersebut cukup relevan. Karena dalam pembelajaran sejarah dalam konteks yang lebih luas, harus juga diberikan 
pemahaman pada kondisi historis yang lebih dekat atau dalam konteks ini sejarah lokal dari mahasiswa atau siswa itu sendiri. Melalui media-media belajar berupa peninggalanpeninggalan yang ada di laboratorium pendidikan sejarah bisa jadi menjadi bagian dari proses integrasi pembelajaran sejarah tersebut.

Sebagai penguatan teoretis, pembelajaran semacam ini juga sesuai dengan perkembangan pendekatan, metode, dan strategi pembelajaran dewasa ini. Dalam pendekatan pembelajaran konstruktifis yang menekankan pada "siswa yang harus aktif membangun pengetahuan dalam pikiran mereka sendiri (Baharuddin \& Esa Nur W, 2008: 115), mendapatkan momentumnya.

\section{METODE PENELITIAN}

Pendekatan penelitian yang digunakan dalam penelitian ini adalah pendekatan penelitian kualitatif. Penelitian kualitatif berusaha memahami fact yang ada di balik kenyataan, yang dapat diamati atau diindra secara langsung. Dalam istilah metode ini, fakta yang berada yang berada di balik kenyataan langsung disebut verstehen (Maryaeni, 2005: 3). Sejalan dengan hal tersebut, verstehen sendiri seperti dijelaskan Kuntowijoyo (2008) dan Hardiman (2003), merupakan pengalaman "dalam" yang menembus jiwa dan seluruh pengalaman kemanusiaan. Demikian juga Max Weber (Kuswarno, 2009) menjelaskan versetehen mengarah pada suatu tindakan bermotif demi tujuan yang hendak dicapai, sebagai salah satu metode untuk memahami motif dan makna di balik tindakan manusia. Adapun metode penelitian yang digunakan adalah metode penomenoligi yang bertujuan untuk menemukan makna dibalik sesuatu yang tampak. Sedangkan metode yang diguanakan adalah metode fenomenologi.

\section{HASIL DAN PEMBAHASAN}

\section{a. Laboratorium Sejarah Sebagai Media Pembelajaran}

Laboratorium program studi (selanjutnya ditulis lab sejarah) pendidikan sejarah yang saat ini masuk dalam Fakltas Ilmu Sosial dan Ekonomi (FISE) Universitas Hamzanwadi merupakan salah satu laboratorium program studi yang cukup lama. Lab sejarah sesuai dengan namanya melekat sebagai museum tempat menyimpan peninggalan-peninggalan sejarah baik berupa fosil, artefak, poto, dan tulisan-tulisan kuno, dan peninggalan sejarah lainnya baik yang merupakan peninggalan lokal bahkan nasional. Khusus untuk peninggalan nasional lebih banyak merupakan miniatur.

Miniatur-miniatur yang menjadi media pembelajaran di lab sejarah secara umum merupakan hasil karya dari mahasiswa pada mata kuliah khusus yaitu pengelolaan laboratorium, serta tugas lain yang diberikan oleh dosen pada saat melakukan Kuliah 
Kerja Lapangan (KKL). Meskipun peninggalan-peninggalan sejarah yang dipajang lebih banyak merupakan miniatur sama sekali tidak mengurangi minat pengunjung untuk memahaminya lebih dalam.

Miniatur lokal seperti masjid Bayan Beleq, makam Kerajaan Selaparang, dan peninggalan-peninggalan lainnya seperti lontar, bedug, dan perlengkapan-perlengkahan sehari-hari yang digunakan masyarakat Sasak merupakan daya tarik tersendiri untuk meningkatkan kesadaran sejarah lokal sebagai bagian dari sejarah nasional itu sendiri. Meskipun pada dasarnya secara keseluruhan miniatur-miniatur sejarah nasional lebih mendominasi mulai dari beberapa candi, miniatur manusia purba sampai pada deorama peristiwa-peristiwa seputar proklamasi dan lain sebagainya.

Koleksi lab sejarah juga dapat diidentifikasi berdasarkan priodesasi mulai dari dari masa praaksara dengan adanya miniatur manusia purba dan beberapa miniatur dinasaurus dan lain sebagainya, berlanjut masa kerajaan-kerajaan Islam dengan miniatur-miniatur masjid kunonya, masa kolonial dengn kapal-kapal-nya, perjuangan kemerdekaan dengan deorama yang cukup menarik sampai pada peristiwa kemerdekaan Republik Indonesia. Sebagai daya tarik lainnya, di lab sejarah juga dipajang beberapa hasil budaya baik dari masyarakat Sasak dan suku lain di Nusa Tenggara Barat.

\section{b. Penugasan Mahasiswa Sebagai Tutor Laboratorium}

Sebagai bagian dari cara untuk meningkatkan kecintaan sejarah pada siswa, program studi pendidikan sejarah melalui keberadaan lab setiap tahun mengundang kedatangan siswa mulai dari SLTP/MTS, SMA/MA/SMK sederajat untuk belajar dan melihat langsung beberapa koleksi seperti miniatur-miniatur dan peninggalan sejarah dan budaya lokal sampai nasional.

Keberadaan laboratorium Prodi Pendidikan Sejarah ini sekaligus menjadi bagian integral dalam proses pembelajaran khususnya bagi mahasiswa mulai dari semester terendah maupun mahasiswa senior. Terlebih lagi keberadaan salah satu mata kuliah yaitu Pengelolaan Laboratorium Sejarah memberikan pembelajaran bagi mahasiswa bagaimana nantinya apabila mereka menjadi guru yang sebenarnya akan mampu menggunakan media dan bahkan membuat media pembelajaran yang mampu menarik siswa untuk lebih cepat memahami dan tentunya lebih termotivasi untuk belajar sejarah.

Pembagian berdasarkan priodesasi ini tujuannya adalah untuk mempermudah mahasiswa supaya lebih fokus dan lebih mudah untuk memahami semua materi yang nantinya akan dijelaskan. Setiap kelompok yang mendapatkan tugas untuk setiap 
priodesasi dipilih secara acak baik berdasarkan gender, kemampuan, dan berdasarkan semester.

Hampir semua mahasiswa Prodi Pendidikan Sejarah dilibatkan dilibatkan sebagai tutor, hanya saja beberapa mahasiswa yang kurang mampu secara akademis untuk menjelaskan pada siswa biasanya hanya mendampingi temannya yang mampu menjelaskan. Dengan adanya pengalaman mengikuti teman-temannya kemudian mereka juga dalam prosesnya mampu menjelaskan setiap objek sejarah dengan baik sesuai dengan priodesasi sejarah.

\section{c. Perkembangan Kemampuan dan Kesadaran Sejarah Mahasiswa}

Secara umum dapat diidentifikasi beberapa kecendrungan mahasiswa yang dilibatkan sebagai tutur di lab sejarah, sebagai berikut:

1. Memiliki kesadaran sendiri untuk memahami materi sesuai dengan tema yang harus dijelaskan.

Secara keseluruhan, siswa yang diberikan tugas untuk menjelaskan setiap objek sejarah yang ada di laboratorium sesuai dengan priodesasinya mereka mampu untuk menjelaskan dengan baik. Hal ini juga terlihat meskupun mahasiswa tersebut untuk mata kuliah tertentu memiliki kemampuan yang kurang, namun dalam konteks ini mereka yang diberikan tugas selain mampu menjelaskan sekaligus mereka siap untuk menjawab pertanyaan-pertanyaan dari setiap siswa. Kemampuan mahasiswa ini terlihat tidak saja ketika ada kunjungan yang biasa, namun juga pada iven-iven tertentu yang pengunjungnya tidak hanya dari sekolah-sekolah terdekat di Lombok Timur namun juga sekolah-sekolah lainnya dari Lombok Tengah maupun Lombok Barat.

Terdapat kesadaran yang cukup tinggi bagi mahasiwa yang diberikan tugas setiap kelompoknya, selain disiapkan literatur yang sesuai dengan petunjuk laboratorium untuk dipahami sebaik mungkin, sekaligus mereka dengan kesadaran sendiri memperkaya wawasannya tentang objek yang akan dijelaskan dengan mencari sumber sendiri baik dari buku maupun internet. Keberadaan internet yang mempermudah mereka untuk mempelajari setiap priodesasi dalam sejarah baik dalam tingkat lokal, nasional, maupun internasional semakin mempermudah siswa untuk memahami dan meningkatkan pemahaman mereka. 
Artinya bahwa dengan diberikannya tanggungjawab oleh pengelola laboratorium mahasiswa memiliki kesadaran sendiri untuk mendalami setiap priodesasi sejarah yang ada tanpa harus diberikan bimbingan yang lama. Sesuai dengan informasi di atas, cukup menarik juga bahwa apabila mahasiswa akan lebih termotivasi untuk belajar tugas laboratorum daripada tugas mata kuliah lain tentu saja akan dapat memberikan masukan pada semua dosen bahwa diperlukan pendekatan, metode media baru yang paling tidak dapat menyentuh dan memotivasi siswa seperti halnya ketika mereka diberikan tugas untuk memahami benda-benda yang ada di laboratorium.

2. Mampu belajar kooperatif terutama dengan kelompoknya.

Penugasan menjadi tutor yang dilakukan secara berkelompok berdasarkan pada beberapa kriteria mulai dari semester, gender, dan kemampuan dirasakan baik oleh mahasiswa maupun dosen secara umum di prodi Pendidikan sejarah semakin memperkuat rasa persaudaraan dan kerja sama yang cukup tinggi pada mahasiswa program studi ini, hal ini tentu saja bukan karena jumlah mereka yang tidak begitu banyak namun tentu saja merupakan konsekuensi dari kebersamaan yang dibangun dalam kegiatan yang melibatkan mereka dalam beberapa kegiatan dan tugas laboratorium sebagai tutor.

Harmonisai antara mahasiswa satu dengan mahasiswa yang lain baik pada semester yang sama maupun yang berbeda dalam mendukung semua kegatan prodi terutama berkaitan dengan laboratorium menunjukkan adanya nilai kebersamaan yang terbangun begitu kuat dari kebersamaan mereka sebagai tutor. Secara keseluruhan diakui bahwa kebersamaan menjadi tutor di laboratorium sekaligus memberikan motivasi yang sama untuk mengerjakan tugas-tugas lain secara Bersama. Lebihnya lagi, mahasiswa yang biasanya kurang suka bergaul.

Satu hal yang menarik juga, apabila ada mahasiswa yang baik secara akademik kurang, begitu juga kurang banyak bergaul dengan teman-temannya akan diminta untuk diikutsertakan dengan maksimal apabila ada kegiatan mahasiswa baik sebagai tutor atau panitia dalam kegiatan tertentu yang dilakukan di laboratorium. Bahkan menguatkan keterlibatan mahasiswa yang kurang aktif dalam setiap kegiatan laboratorium sekaligus menjadi bagian dari instruksi ketua Program Studi Pendidikan Sejarah itu sendiri. 
Contoh menarik, ketika Program Studi Pendidikan Sejarah mengadakan kegiatan "Peringatan Hari Sejarah" dengan mengadakan pameran laboratorium Sejarah, selain Himpunan Mahasiswa Program Studi sebagai panitia, dimasukkan juga beberapa mahasiswa yang selama ini dianggap kurang aktif dalam kepanitiaan ini. Hal ini salah satu tujuannya adalah untuk membiasakan mereka bekerjasama dengan mahasiswa lainnya. Artinya bahwa secara keseluruhan kegiatan mahasiswa di Laboratorium Pendidikan Sejarah telah menjadi salah satu perekat hubungan antar mahasiswa.

3. Mampu mengekspresikan kemampuan berbicaranya dengan baik terutama pada siswa yang datang berkunjung.

Salah satu cara untuk melatih kemampuan mahasiswa untuk berbicara dan dirasakan cukup epektif di Program Studi Pendidikan Sejarah adalah dengan memberikan tugas pada setiap mahasiswa untuk mengambil bagian sebagai tutor pada saat kunjungan siswa ke Laboratorium Pendidikan Sejarah.

Tidak sedikit mahasiswa yang pada saat semester 1 (satu) kurang berani berbicara di depan teman-temannya, setelah beberapa kali diberikan tanggung jawab sebagai tutor pada semester berikutnya akan menjadi terbiasa untuk baik menyempaikan pendapat maupun bertanya pada saat kuliah biasa.

Kemampuan untuk berbicara dan menjelaskan materi ini dirasakan betul berpengaruh dalam kegiatan perkuliahan, meskipun dalam tahapan perkembangan yang berbeda-beda antara setiap mahasiswa. Karena ada saja mahasiwa yang butuh proses yang cukup lama misalnya sekitar 3 (tiga) semester untuk membiasakan dirinya.

4. Bertanggungjawab atas tugas-tugas lain yang diberikan

Penugasan sebagai tutor juga berpengaruh terhadap motivasi belajar mahasiswa, dimana ketika ada informasi bahawa aka nada kunjungan dari sekolah maka secara tidak langsung mereka menyatakan siap untuk menjadi tutor tanpa harus diminta satu per satu. Artinya bahwa dengan kebiasaan yang ada mahasiswa hamper di setiap jenjang semester siap untuk dijadikan tutor dan tentu saja berdasarkan priodesasi yang pernah mereka dapat sebelumnya.

Motivasi ini sebenarnya tidak berdiri sendiri, secara psikologis mahsiswa merasa lebih senang apabila mereka mampu menarik perhatian anak-anak seusia 
SMA, dan ini secara tidak langsung menguatkan motivasi mereka untuk selalu siap apabila ada siswa yang akan dating berkunjung, bahkan tidak jarang mereka bertanya sendiri kapan aakan ada kunjungan lagi sehingga mereka lebih cepat untuk mempersiapkan diri. Dan hal ini tentu saja menjadi motivasi eksternal bagi mahasiswa.

\section{KESIMPULAN}

Penugasan sebagai tutor di Laboratorium Pendidikan Sejarah Fakultas Ilmu Sosial dan Ekonomi (FISE) Universitas Hamzanwadi memiliki banyak dampak positif pada mahasiswa secara keseluruhan, karena hampir semua mahasiswa di Prodi Pendidikan Sejarah pada saat-saat tertentu akan diminta menjadi tutor yang akan menjelaskan mengenai koleksi laboratorium.

Mahasiswa dalam penugasan sebagai tutor diberikan tugas secara berkelompok yang bertugas untuk menjelaskan setiap priodesasi dalam sejarah Indonesia, dimana satu kelompok untuk satu priode sejarah. Bahkan untuk priode sejarah pada priode tertentu namun memiliki objek yang banyak bisa saja dijelaskan oleh dua kelompok.

Beberapa dampak positif tugas tutor yang diberikan pada siswa di Program Studi Pendidikan Sejarah dapat diidentifikasi sebagai berikut:

1. Memiliki kesadaran sendiri untuk memahami materi sesuai dengan tema yang harus dijelaskan. Secara keseluruhan, siswa yang diberikan tugas untuk menjelaskan setiap objek sejarah yang ada di laboratorium sesuai dengan priodesasinya mereka mampu untuk menjelaskan dengan baik. Hal ini juga terlihat meskupun mahasiswa tersebut untuk mata kuliah tertentu memiliki kemampuan yang kurang, namun dalam konteks ini mereka yang diberikan tugas selain mampu menjelaskan sekaligus mereka siap untuk menjawab pertanyaan-pertanyaan dari setiap siswa. Kemampuan mahasiswa ini terlihat tidak saja ketika ada kunjungan yang biasa, namun juga pada iven-iven tertentu yang pengunjungnya tidak hanya dari sekolah-sekolah terdekat di Lombok Timur namun juga sekolah-sekolah lainnya dari Lombok Tengah maupun Lombok Barat.

2. Mampu belajar kooperatif terutama dengan kelompoknya. Penugasan menjadi tutor yang dilakukan secara berkelompok berdasarkan pada beberapa kriteria mulai dari semester, gender, dan kemampuan dirasakan baik oleh mahasiswa maupun dosen secara umum di prodi Pendidikan sejarah semakin memperkuat rasa persaudaraan dan kerja sama yang cukup tinggi pada mahasiswa program studi ini, hal ini tentu saja bukan karena jumlah mereka yang tidak begitu banyak namun tentu saja merupakan 
Penugasan Tutor ..... Lalu Murdi, Bambang Eka Saputra

konsekuensi dari kebersamaan yang dibangun dalam kegiatan yang melibatkan mereka dalam beberapa kegiatan dan tugas laboratorium sebagai tutor.

\section{DAFTAR PUSTAKA}

Agung, Leo \& Sri Wahyuni. (2013). Perencanaan Pembelajaran Sejarah. Yogyakarta: Ombak.

Alsa, Asmadi. (2004). Pendekatan Kuantitatif \& Kualitatif Serta Kombinasinya dalam Penelitian Psikologi. Yogyakarta: Pustaka Pelajar.

Al-Tabani, Trianto, I, B. (2018). Mendesain Model Pembelajaran Inovatif, Progresif dan Kontekstual. Jakarta: Kencana.

Aman. (2011). Model Evaluasi Pembelajaran Sejarah. Yogyakarta: Ombak.

Badarudin \& Lalu Murdi. (2016). Integrasi Sejarah Lokal dalam Paket Pengajaran Sejarah Nasional. Prosiding Seminar Nasional Program Studi Pendidikan Sejarah se-Indonesia: Kajian Muatan dan Posisi Mata Pelajaran Sejarah di Kurikulum 2013. Yogyakarta: Tim Penerbit Fakultas Ilmu Sosial Universitas Negeri Yogyakarta.

Baharuddin \& Esa Nur W. (2008). Teori Belajar dan Pembelajaran. Yogyakarta: ArRuzz Media.

Kuswarno, Engkus. (2009). Metodologi Penelitian Komunikasi Fenomenologi: Konsep, Pedoman, dan Contoh Penelitiannya. Bandung: Widya Padjajaran. 